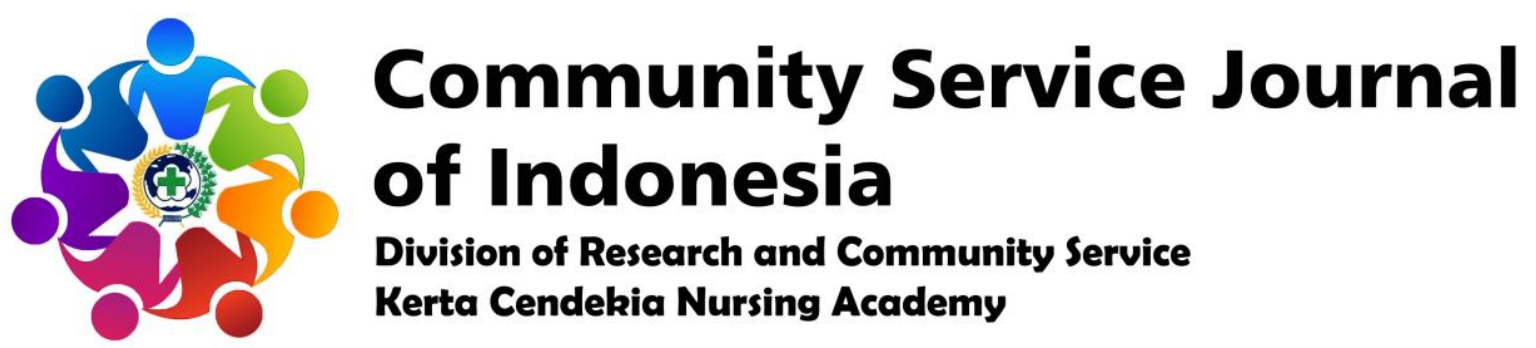

https://ejournal-kertacendekia.id/index.php/csji/index

Community Service Journal of Indonesia 2 (1) (2020): 1-3

Doi: https://doi.org/10.36720/csji.v2i1.137

\title{
KNOWLEDGE IMPROVEMENT OF YOUTH ORGANIZATION AND HEALTH'S CADRES OF FIRST AID IN ACCIDENT AT RANGKAH KIDUL VILLAGE
}

\author{
Kusuma Wijaya Ridi Putra ${ }^{\mathbf{1}}$, Riesmiyatiningdyah Riesmiyatiningdyah ${ }^{\mathbf{1}}$, Meli Diana ${ }^{\mathbf{1}}$, \\ Agus Sulistyowati ${ }^{1}$, Faida Annisa ${ }^{1}$, Dini Prastyo Wijayanti ${ }^{1}$, Marlita Dewi Lestari ${ }^{1}$
}

${ }^{1}$ Lecturer of Kerta Cendekia Nursing Academy, Sidoarjo

\begin{abstract}
First Aid Training in Accidents in Youth Organization and Health Care Cadres in Rangkah Kidul Village is one form of community service in the form of counseling aimed at increasing the understanding and skills of the general public towards first aid in accidents. The implementation of these activities on December 7, 2019 took place at the Rangkah Kidul Village Hall, Sidoarjo District, Sidoarjo Regency. The target is Youth Organization and Health Cadre of Rangkah Kidul Village, Sidoarjo. Before the activity is carried out, there is a process of compiling the activity for approximately 2 months before the activity is carried out, starting from determining the theme of the training to applying for permission to the parties concerned. As a form of evaluation, the activity was attended by 28 participants consisting of Health's Cadres, Youth Organization, Village Officials, Head of RT / RW, and LKMD representatives. Participants participated in the activity with enthusiasm and seemed very enthusiastic, the training activities could run on time and smoothly.
\end{abstract}

Keywords: Training of the first aid in accident, youth organization, health's cadre.

(c) 2020 The Authors. Community Service Journal of Indonesia Published by Community Service and Research of Kerta Cendekia Nursing Academy - Kerta Cendekia Nursing Academy

This is an Open Access Article distributed under the terms of the Creative Commons Attribution 4.0 International License which permits unrestricted non-commercial use, distribution, and reproduction in any medium, provided the original work is properly cited.

E-ISSN

2684-7884

\section{INTRODUCTION}

With increasing mobility and distance, people need vehicle aids for their mobility. The increasing number of motor vehicles, the incidence of accidents is very high. Often the handling / first aid given is not in accordance with the principles of the first aid available. This can worsen the condition of the accident victim himself. Efforts to increase knowledge and skills in handling / first aid in accidents. One such improvement effort is the holding of first aid training in accidents to the general public. To that end, as an effort is to carry 
out community service in the form of first aid training in accidents in Youth Organization and Health's Cadre of Rangkah Kidul Village, Sidoarjo.

\section{OBJECTIVES}

General Purpose

After the first aid training in accidents can know, understand, and practice properly and correctly about the procedures for first aid in an accident.

\section{Special Purpose}

After the first aid training in accidents, it is expected that members of the Youth Organization and the Health's Cadre of Rangkah Kidul Village can:

1. Knowing the things that need to be considered in doing first aid in an accident.

2. Know the steps in providing first aid to a good and correct accident.

3. Apply the first aid procedure to a good and correct accident.

\section{PLAN OF ACTION}

\section{Strategy Plan}

The strategy plan implemented, including:

1. Coordinate with the village head and the Head of Youth Organization and the Health's Cadre of Rangkah Kidul Village, Sidoarjo District, Sidoarjo Regency to request permission to conduct training.

2. Implementation time contract with Youth Organization and Rangkah Kidul Village Health Cadre.

3. Providing First Aid training in Accidents (P3K) to Youth Organization and Rangkah Kidul Village Cadres.

\section{Implementation}

Actions taken in the implementation of these activities, including:

1. Contacted the head of Rangkah Kidul Village, Youth Organization, Health Cadre of Rangkah Kidul Village, Sidoarjo District, Sidoarjo Regency and coordinate the implementation.

2. Prepared the place and media for first aid training in accidents.

3. Carried out of first aid training in accidents for Youth Organizations and Health Cadres in Rangkah Kidul Village, Sidoarjo District, Sidoarjo Regency.

\section{Setting}

This activity was carried out at the Rangkah Kidul Village Hall, Sidoarjo District, Sidoarjo Regency.

Target

Target in this activity is all of the youth organization and health cadres of Rangkah Kidul Village, Sidoarjo District, Sidoarjo Regency.

\section{RESULTS AND DISCUSSION}

The activity starts at 20.00 and ends at 22.00, the counseling time must be delayed for 1 hour from the original schedule due to waiting for participants to gather. The activity was carried out at the Rangkah Kidul Village Hall, Sidoarjo District, Sidoarjo Regency. The activity was attended by 28 participants consisting of Health Cadres, Youth Organization, Village Officials, Head of RT / RW, and LKMD representatives.

Equipment used during the counseling process are laptops, powerpoints, videos, leaflets, lcd, posters, phantom RJP Full Body. Using simple language and sentences, participants respond with 
enthusiasm. The participants seemed conducive in the process of delivering the material. Activities in the form of providing training materials, demonstrations, practices. Participants are able to practice the first aid application directly on the accident correctly. The government of Rangkah Kidul Village is willing to cooperate in the implementation of first aid training activities in accidents.

Every question asked by participants can be answered by all members of the health promotion team. $90 \%$ of participants are able to understand the material presented. $85 \%$ of participants were able to apply the material presented related to first aid in an accident.

\section{CONCLUSION}

Knowledge improvement of youth organization and health's cadres of first aid in accident at Rangkah Kidul Village was considered quite successful because $90 \%$ of participants are able to understand the material presented. $85 \%$ of participants were able to apply the material presented related to first aid in an accident.

\section{REFERENCES}

(2019). Pertolongan Pertama pada

Kecelakaan: Apa yang Harus

Dilakukan?. Retrieved from

https://medi-

call.id/blog/pertolongan-pertama-

pada-kecelakaan/ on October 10,

2019.

--------. Pertolongan Pertama pada

Kecelakaan (P3K). Retrieved from

http://dinus.ac.id/repository/docs/aj

ar/P3K.pdf on October 10, 2019.
-------. Pertolongan Pertama pada

Kecelakaan (P3K). Retrieved from

http://staffnew.uny.ac.id/upload/19

7912032015042001/pendidikan/PE

RTEMUAN\%209-

10\%20PPPK.pdf on October 10, 2019.

Saputra, W. (2014). Pertolongan Pertama pada Kecelakaan (P3K). Retrieved from

https://wandasaputra93.wordpress. com/2014/01/19/158/ on October 10, 2019. 